\title{
Distinct Species Exist Within the Cercospora apii Morphotype
}

\author{
Marizeth Groenewald, Johannes Z. Groenewald, and Pedro W. Crous
}

First and third authors: Laboratory of Phytopathology, Wageningen University, Binnenhaven 5, 6709 PD Wageningen, The Netherlands; and first, second, and third authors: Centraalbureau voor Schimmelcultures, Fungal Biodiversity Centre, Uppsalalaan 8, 3584 CT Utrecht, The Netherlands.

Accepted for publication 13 April 2005.

\begin{abstract}
Groenewald, M., Groenewald, J. Z., and Crous, P. W. 2005. Distinct species exist within the Cercospora apii morphotype. Phytopathology 95:951-959.

The genus Cercospora is one of the largest genera of hyphomycetes. Cercospora apii sensu lato is the oldest name for a large complex of morphologically indistinguishable Cercospora spp. occurring on a wide host range. There are currently 659 recognized Cercospora spp., and names of another 281 morphologically identical species are included in the synonymy of $C$. apii sensu lato. Two of the species that belong to the C. apii complex, $C$. apii and $C$. beticola, cause Cercospora leaf spot on Apium graveolens (celery) and Beta vulgaris (sugar beet), respectively. In

the present study, multilocus sequence data, amplified fragment length polymorphism analysis, and cultural characteristics were used as additional features to characterize morphologically similar Cercospora strains occurring on celery and sugar beet. From the data obtained, it is shown that $C$. apii and C. beticola, although morphologically similar and able to cross-infect each others' hosts, are distinct functional species that should be retained as separate entities. Furthermore, a third, as yet undescribed species of Cercospora was detected in celery fields in Korea and Venezuela, suggesting that additional undescribed species also may be found to cause Cercospora leaf spot on celery. A polymerase chain reactionbased diagnostic protocol distinguishes all three Cercospora spp.
\end{abstract}

In his monograph of the genus Cercospora Fresen., Chupp (6) accepted 1,419 species. In total, more than 3,000 species of Cercospora have been described, of which 659 presently are recognized (7). Generally, species of Cercospora are considered to be host specific (6) at the level of the plant genus or family; this concept has led to the description of a large number of species. Several Cercospora spp., which are morphologically indistinguishable from Cercospora apii Fresen., were placed in the C. apii complex (13). Cross-inoculation studies revealed that isolates in the $C$. apii complex can infect an extremely wide host range, including Apium graveolens (celery) and Beta vulgaris (sugar beet) $(1,2,22,23,38,42)$. In their revision of the genus Cercospora, Crous and Braun (7) referred 281 morphologically indistinguishable species to the $C$. apii sensu lato complex. Recent genetic analyses of Cercospora spp. have relied mainly on DNA sequences of the internal transcribed spacers (ITSs) and the 5.8S ribosomal (r)RNA gene. These studies have revealed that most species of Cercospora, in particular the members of the C. apii complex, are identical or very closely related $(18,30,36$, 37). Judging from their morphological similarity as well as their proven cross-infectiveness, it is probable that the species in the C. apii complex should be considered synonymous.

Species seen as representative of $C$. apii sensu lato lack a known teleomorph. Although the genus Cercospora is a wellestablished anamorph of the genus Mycosphaerella $(11,18)$, only a few teleomorphs have been elicited via cultural studies $(7,9)$. Phylogenetic analyses of all Cercospora isolates to date have placed them as a well-defined clade in the genus Mycosphaerella. Therefore, if a teleomorph were to be found for $C$. apii, it should be a species of Mycosphaerella $(11,18,30,36)$.

Corresponding author: M. Groenewald; E-mail address: groenewald@cbs.knaw.nl

DOI: 10.1094/PHYTO-95-0951

(C) 2005 The American Phytopathological Society
C. beticola, causal agent of Cercospora leaf spot on B. vulgaris, originally was described by Saccardo (34), and is assumed to have originated in central Europe and the Mediterranean area. C. apii, which causes Cercospora leaf spot on A. graveolens, was described from the region between The Netherlands and Germany (15), and is assumed to have originated in Western Europe. C. beticola is seen as part of the $C$. apii complex $(7,13)$. Several studies so far have suggested that $C$. beticola on sugar beet should be treated as a synonym of $C$. apii $(2,13,22,38,42)$.

Cercospora leaf spot on sugar beet is a serious problem wherever this crop is grown. It is one of the most common and destructive sugar beet diseases, affecting more than a third of all fields worldwide $(20,35)$. A whole sugar beet field can be destroyed by an outbreak of $C$. beticola, resulting in complete loss of the crop $(12,32,41)$.

The similarity in disease symptoms and pathogen morphology seen in celery and sugar beet Cercospora leaf spot diseases led Crous and Braun (7) to conclude that $C$. beticola should be treated as a synonym of $C$. apii sensu lato. Although Cercospora leaf spot is no longer considered the most destructive disease on celery (26), in some parts of the world (e.g., Florida), C. apii is still seen as a serious pathogen of this crop (27).

The main objective of the present study was to confirm or reject the synonymy of $C$. apii and $C$. beticola. It was felt that the same study would provide some indication as to the status of a large number of the purported synonyms of $C$. apii. To address these matters, 38 Cercospora isolates were collected from sugar beet and celery; representing a total of 13 countries. Isolates were subjected to multigene sequence analysis and amplified fragment length polymorphism (AFLP) analysis, as well as cultural and morphological comparisons. Here, we show that both celery and sugar beet are hosts to two species of Cercospora, with one of these species infecting both hosts. Although $C$. apii and $C$. beticola are able to cross-infect each other's hosts and are morphologically similar to one another, they still appear to operate as functional species on their respective primary namesake hosts in nature. 


\section{MATERIALS AND METHODS}

Fungal isolates. Single-spore isolations were obtained from symptomatic celery and sugar beet leaves, and cultures were established on $2 \%$ malt extract agar (MEA) (16) (Table 1). The Cercospora isolates were examined morphologically to confirm their identity as $C$. apii sensu stricto as described by Crous and Braun (7). Some reference isolates were obtained from the Centraalbureau voor Schimmelcultures (CBS) culture collection in Utrecht, The Netherlands.

Morphological and cultural characterization. Cercospora reference strains were selected from celery and sugar beet for morphological and cultural characterization (Table 1). Strains were plated onto 2\% MEA and oatmeal agar (OA) (16) and incubated at $24^{\circ} \mathrm{C}$ in the dark for 8 days. Colony characteristics were determined and colors rated on the different growth media using a color chart (31). Cardinal growth temperatures were determined on MEA (8). These plates were incubated in the dark for 8 days at temperatures beginning at $6^{\circ} \mathrm{C}$ and progressing to $36^{\circ} \mathrm{C}$ in $3^{\circ} \mathrm{C}$ intervals; in addition, growth at $40^{\circ} \mathrm{C}$ was studied. Several isolates taken from each of the three different groups were used (Table 1). The experiments featured three simultaneous replicates for each isolate; the whole trial was repeated once.

DNA extraction and sequencing. DNA analysis was done on all isolates listed in Table 1. The FastDNA kit (BIO 101, Carlsbad, CA) was used according to the manufacturer's instructions to isolate genomic (g)DNA of 200 to $400 \mathrm{mg}$ of fungal mycelia grown on MEA plates for 8 days at $24^{\circ} \mathrm{C}$. A sterile blade was used to scrape the mycelia from the surface of the plate. The primers ITS1 and ITS4 (43) were used to amplify the ITS areas as well as the 5.8S rRNA gene (ITS). Part of the actin (ACT) gene was amplified using the ACT512F and ACT783R primers (4) and part of the translation elongation factor (EF) $1-\alpha$ gene using the primers EF728F and EF986R (4). The CAL228F and CAL737R primers (4) were used to amplify part of the calmodulin (CAL) gene, and the primers CylH3F and CylH3R (10) to amplify part of the histone H3 (HIST) gene. The polymerase chain reaction (PCR) conditions were the same for all regions, except for the $\mathrm{MgCl}_{2}$ concentration, which was $2 \mathrm{mM}$ for the CAL region and $1.5 \mathrm{mM}$ for the remaining areas. The reaction mixture had a total volume of $12.5 \mu \mathrm{l}$ and contained $1 \mu \mathrm{l}$ of diluted gDNA, $1 \times$ PCR buffer, $48 \mu \mathrm{M}$ each of the dNTPs, 2.5 pmol of each primer, and 0.7 units $\mathrm{Taq}$ polymerase (Bioline $\mathrm{GmbH}$, Luckenwalde, Germany). The amplification reactions were done on a GeneAmp PCR System 9600 (Perkin-Elmer, Norwalk, CT). The initial denaturation step was done at $94^{\circ} \mathrm{C}$ for $5 \mathrm{~min}$, followed by 40 cycles of denaturation at $94^{\circ} \mathrm{C}(30 \mathrm{~s})$, annealing at $52^{\circ} \mathrm{C}(30 \mathrm{~s})$, and elongation at $72^{\circ} \mathrm{C}(30 \mathrm{~s})$. A final elongation step at $72^{\circ} \mathrm{C}(7 \mathrm{~min})$ was included in the run. The PCR products were separated by electrophoresis at $80 \mathrm{~V}$ for $40 \mathrm{~min}$ on a $0.8 \%$ (wt/vol) agarose gel containing ethidium bromide at $0.1 \mu \mathrm{g} / \mathrm{ml}$ in $1 \times$ Tris-acetateEDTA buffer (0.4 M Tris, $0.05 \mathrm{M} \mathrm{NaAc,} \mathrm{and} \mathrm{0.01} \mathrm{M} \mathrm{EDTA,}$ $\mathrm{pH}$ 7.85) and visualized under UV light.

The amplicons were sequenced in both directions using the PCR primers and a DYEnamic ET Terminator Cycle Sequencing kit (Amersham Biosciences, Roosendal, The Netherlands) according to the manufacturer's recommendations. The products were analyzed on an ABI Prism 3700 DNA Sequencer (Perkin-Elmer, Foster City, CA). A consensus sequence was computed from the forward and reverse sequences with SeqMan from the Lasergene package (DNAstar, Madison, WI).

Phylogenetic analysis. The sequences were assembled and added to the outgroups using Sequence Alignment Editor (version 2.0a11; Department of Zoology, University of Oxford, Oxford, UK), and manual adjustments for improvement were made by eye where necessary. The phylogenetic analyses of sequence data were done in Phylogenetic Analysis Using Parsimony (PAUP; version 4.0b10; Sinauer Associates, Sunderland, MA) and con- sisted of neighbor-joining analysis with the uncorrected ("p"), Jukes-Cantor, and Kimura 2-parameter substitution models. Alignment gaps were treated as missing data and all characters were unordered and of equal weight. Any ties were broken randomly when encountered. For parsimony analysis, alignment gaps were treated as a fifth character state and all characters were unordered and of equal weight. Maximum parsimony analysis was performed for all data sets using the heuristic search option with 100 random taxa additions and tree bisection and reconstruction as the branch-swapping algorithm. Branches of zero length were collapsed and all multiple, equally parsimonious trees were saved. The robustness of the trees obtained was evaluated by 1,000 bootstrap replications (19). Other measures calculated included tree length, consistency index, retention index, and rescaled consistency index (TL, CI, RI, and RC, respectively). The resulting trees were printed with TreeView version 1.6.6 (29). A partition homogeneity test was done in PAUP to test whether the different loci can be used in a combined analysis (14). Sequences were deposited in GenBank (accession numbers listed in Table 1) and the alignments in TreeBASE (accession no. S1285).

AFLP analysis. Restriction enzyme digestion and adaptor ligation were done using $30 \mathrm{ng}$ of gDNA, $1 \times$ T4 DNA ligase buffer, $50 \mathrm{mM} \mathrm{NaCl}, 2 \mathrm{U}$ of MseI, 2 units of EcoRI, $40 \mathrm{U}$ of T4 DNA ligase, $10 \mu \mathrm{g}$ of bovine serum albumin, $50 \mathrm{pmol}$ of $\mathrm{MseI}$ adaptor, and 5 of pmol EcoRI adaptor made up to a final volume of $11 \mu \mathrm{l}$ (39). All enzymes were obtained from New England BioLabs (Beverly, MA). This reaction was carried out at $37^{\circ} \mathrm{C}$ for $12 \mathrm{~h}$. A $1: 1$ dilution was made with $\mathrm{dH}_{2} \mathrm{O}$ and $4 \mu \mathrm{l}$ was used in the preselective PCR. The preselective PCR was performed in a $20-\mu 1$ volume containing 25 pmol of primer EcoRI-0 (39), 25 pmol of primer MseI-0 (39), $1.5 \mathrm{mM} \mathrm{MgCl} 2,1 \times$ Bioline Taq reaction buffer, $0.1 \mathrm{mM}$ each dNTP and, 0.75 units of Bioline Taq polymerase. An initial $72^{\circ} \mathrm{C}$ step was done for $2 \mathrm{~min}$, followed by 20 cycles of denaturation at $94^{\circ} \mathrm{C}(20 \mathrm{~s})$, annealing at $56^{\circ} \mathrm{C}(40 \mathrm{~s})$, and elongation at $72^{\circ} \mathrm{C}(1 \mathrm{~min})$. The preselective amplification was confirmed by electrophoresis on a $0.8 \%$ (wt/vol) agarose gel as described above. The preamplified DNA was diluted 1:1 with $\mathrm{dH}_{2} \mathrm{O}$ and used as template for selective amplification. Primers used in the selective amplification were EcoRI-A [FAM]/MseICT, EcoRI-AT [JOE]/MseI-C, and EcoRI-AG [NED]/MseI-C (Applied Biosystems, Nieuwerkerk aan de IJssel, The Netherlands). The reactions contained $1.5 \mathrm{mM} \mathrm{MgCl}, 0.5$ units of Bioline $\mathrm{Taq}$ polymerase, $1 \times$ Bioline Taq polymerase buffer, $0.1 \mathrm{mM}$ each dNTP, $0.5 \mu \mathrm{l}$ of EcoRI primer, and $0.5 \mu \mathrm{l}$ of MseI primer made up to a final volume of $10 \mu \mathrm{l}$. Selective PCR products $(2 \mu \mathrm{l})$, amplified with the different primer combinations for each of the isolates, were mixed together with $0.5 \mu$ of GeneScan 500 (labeled with 6-carboxy-X-rhodamine) (Applied Biosystems) and made up to a final volume of $25 \mu \mathrm{l}$ with formamide. The products were denatured at $100^{\circ} \mathrm{C}$ for $5 \mathrm{~min}$, followed by 30-min runs on an ABI 310 genetic analyzer. The AFLP data were analyzed using Bionumerics software (version 2.5; Applied Maths, Kortrijk, Belgium).

Development of a species-specific diagnostic test. The CAL gene was found to be very effective for separating the three species described in the present study; therefore, this area was targeted for the development of a species-specific diagnostic test. Primers CercoCal-F and CercoCal-R (Table 2) were designed from regions of the CAL gene that are conserved for the Cercospora spp. in our database. They act as outer primers and their amplification functions as a positive control. Three internal primers (CercoCal-beta, CercoCal-apii, and CercoCal-sp), each specific for one of the three Cercospora spp. described in this study, were designed. The species-specific primers were used in separate PCRs together with the outer control primers. Strains of $C$. beticola, C. apii, the undescribed Cercospora sp., and 13 other species of Cercospora (Table 1) were screened with these primers. The sequences and specific nucleotide binding sites of the primers 
TABLE 1. Cercospora isolates included in the study

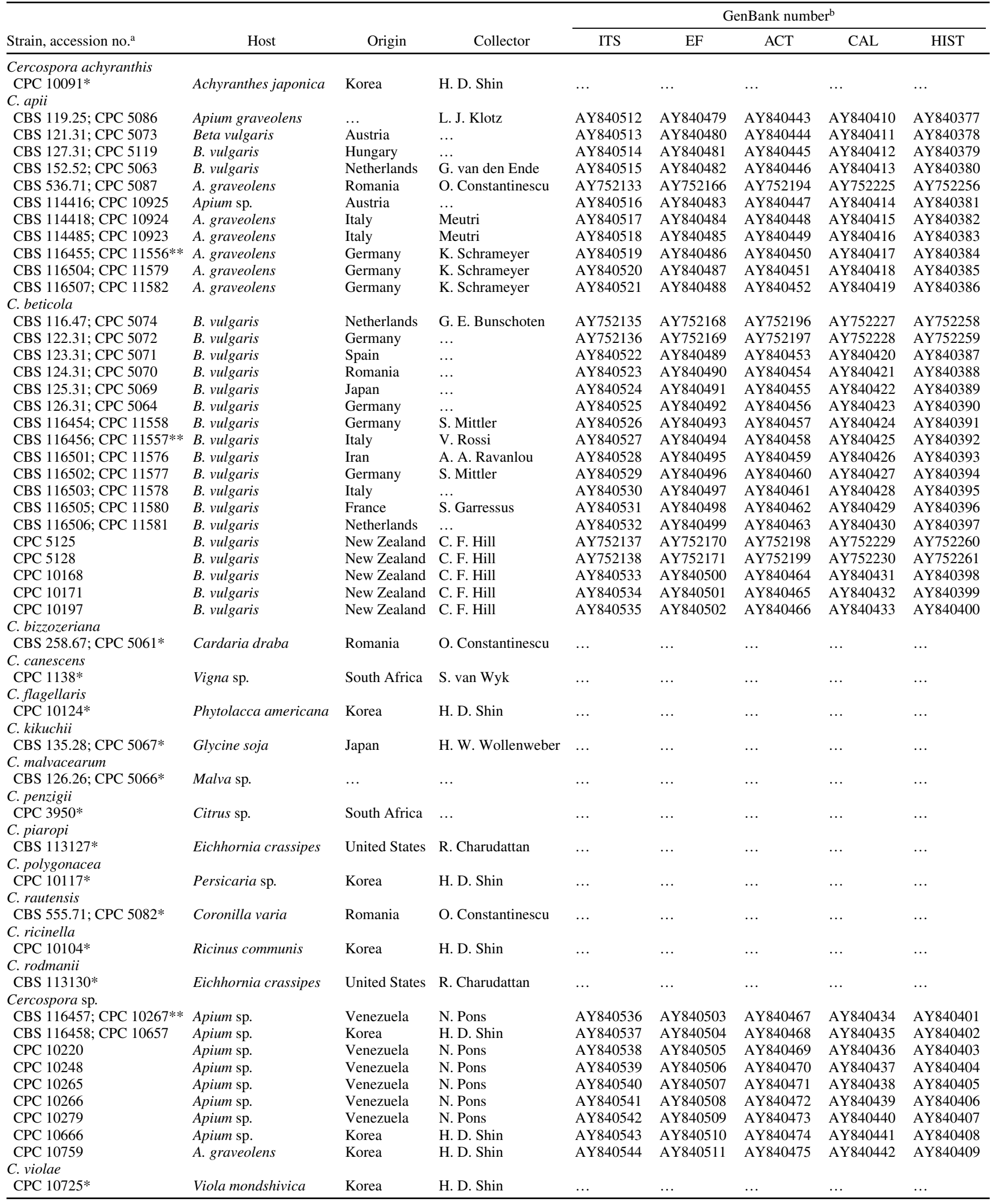

\footnotetext{
a Origin of strain numbers: CBS = Centraalbureau voor Schimmelcultures, Utrecht, The Netherlands and CPC = Collection of Pedro Crous, The Netherlands;

* indicates additional Cercospora spp. tested with the species-specific primers; ** indicates C. apii, C. beticola, and Cercospora sp. isolates used for colony characteristics as well as growth rate measurements.

${ }^{\mathrm{b}} \mathrm{ITS}=$ internal transcribed spacer, $\mathrm{EF}=$ elongation factor, $\mathrm{ACT}=$ actin, $\mathrm{CAL}=$ calmodulin, $\mathrm{HIST}=$ histone $\mathrm{H} 3$.
} 
are listed in Table 2. The same PCR conditions were used for the detection of all three species. The reaction mixture had a total volume of $12.5 \mu \mathrm{l}$ and contained $1 \mu \mathrm{l}$ of diluted gDNA, 1× PCR buffer, $1.5 \mathrm{mM} \mathrm{MgCl}_{2}, 48 \mu \mathrm{M}$ each of the dNTPs, 1 pmol of CercoCal-F, 3 pmol of each of CercoCal-R and the specific internal primer, and 0.7 units (Bioline) of Taq polymerase. The amplification reactions were done on a GeneAmp PCR System 9600 (Perkin-Elmer, Norwalk, CT). The initial denaturation step was done at $95^{\circ} \mathrm{C}$ for $5 \mathrm{~min}$, followed by 40 cycles of denaturation at $95^{\circ} \mathrm{C}(30 \mathrm{~s})$, annealing at $58^{\circ} \mathrm{C}(30 \mathrm{~s})$, and elongation at $72^{\circ} \mathrm{C}(30 \mathrm{~s})$. A final elongation step at $72^{\circ} \mathrm{C}(7 \mathrm{~min})$ was included to ensure that full-length products were obtained. The PCR products were separated on a $1.5 \%$ agarose gel and visualized as described above.

\section{RESULTS}

Morphological and cultural characterization. The morphological characteristics of the conidia and conidiophores for all isolates obtained from celery and sugar beet (Table 1) were the same as described for C. apii sensu lato by Crous and Brown (7). Isolates from celery obtained from Venezuela and Korea were distinct, however, in that conidiophores were relatively short, 25 to 70 by 4 to $6 \mu \mathrm{m}$, and conidia were obclavate-cylindrical, not acicular. They measured (minimum length, 50) 80 to 120 (maximum length, 150) by (minimum width, 3) 4 to $5 \mu \mathrm{m}$ and were one to six septate.

To facilitate the standardization of further genotypic studies on the $C$. apii complex, we herewith designate new epitype (a specimen selected to serve as an interpretative type in support of other type material, to facilitate the precise application of the published name) materials with cultures for $C$. apii and $C$. beticola. For C. apii, the original herbarium material used for the type ("holotype") has been lost, but some of the original material might have been distributed and a lectotype, therefore, can be designated from these duplicates. Isolectotypes are duplicate specimens of the same lectotype. All of the material originally associated with the publication of the name $C$. beticola has been lost; therefore, a specimen has to be designated to serve as if it were the holotype of the species ("neotype"). Isoneotypes are duplicate specimens of the neotype and ex-epitype cultures (to facilitate molecular studies) are derived from the epitype material.

Cercospora apii Fresen., Beitr. Mykol. 3:91. 1863.

Lectotype (proposed here): on Apium graveolens, Germany, Oestrich, garden, Fuckel, Fungi rhen. 117, in HAL. Fresenius (15) cited material of $C$. apii obtained from Fuckel. This is an indirect reference to the material distributed by Fuckel as Fungi rhen. 117. Original material in the herbarium of Fresenius could not be traced, and probably is not preserved; therefore, we prefer to select one of the duplicates distributed by Fuckel to serve as lectotype. Isolectotypes: Fuckel, Fungi rhen. 117. Epitype (proposed here): on Apium graveolens, Germany, Landwirtschaftsamt Heilbronn, 10.08.2004, K. Schrameyer, culture ex-epitype CBS 116455.

Cercospora beticola Sacc., Nuovo Giorn. Bot. Ital. 8:189. 1876.

Neotype (proposed here): on Beta vulgaris, Italy, Vittorio (Treviso), Sept. 1897, Sacc., Fungi ital. 197 (PAD). Isoneotypes: Sacc., Fungi ital. 197. Epitype (proposed here): on Beta vulgaris,
Italy, Ravenna, 10.7.2003, Rossi V., culture ex-epitype CBS 116456.

Colonies of $C$. beticola and $C$. apii are smooth, erumpent, and regular, with smooth, even margins, and sparse to moderate aerial mycelium. $C$. beticola colonies on MEA are greenish-gray on the surface and dark mouse-gray beneath. On OA, colonies are white to green-olivaceous. $C$. apii colonies on MEA are pale greenishgray on the surface and dark mouse-gray beneath. The surfaces of the colonies are white to green-olivaceous on OA. Morphologically divergent isolates from Venezuela and Korea are smooth to folded, erumpent with smooth, even to uneven margins, and sparse to moderate aerial mycelium. On MEA, colonies are white to smoke-gray on the surface, and olivaceous-gray to iron-gray beneath. On OA, colonies are white to olivaceous-gray on the surface.

The temperature ranges and colony diameters of three reference isolates (CBS 116455, CBS 116456, and CBS 116457), representing each of the three different species, are given in Figure 1. The Venezuela and Korea isolates can grow at lower temperatures $\left(6^{\circ} \mathrm{C}\right)$ than $C$. beticola and $C$. apii $\left(12^{\circ} \mathrm{C}\right)$, whereas $C$. beticola and $C$. apii have a higher maximum temperature tolerance $\left(33^{\circ} \mathrm{C}\right)$ than the Cercospora sp. $\left(30^{\circ} \mathrm{C}\right)$. The optimal temperature for growth of the Cercospora sp. was observed to be $24^{\circ} \mathrm{C}$, whereas the optimal growth temperature for $C$. apii and $C$. beticola is $27^{\circ} \mathrm{C}$. The Cercospora sp. grows much more slowly than the other two species, growing only $1.72 \mathrm{~mm} /$ day at its optimum temperature, whereas $C$. beticola and $C$. apii grew 3.5 and $2.7 \mathrm{~mm} /$ day at their respective optimal temperatures. Differences in growth rate between $C$. apii and $C$. beticola were observed for most of the

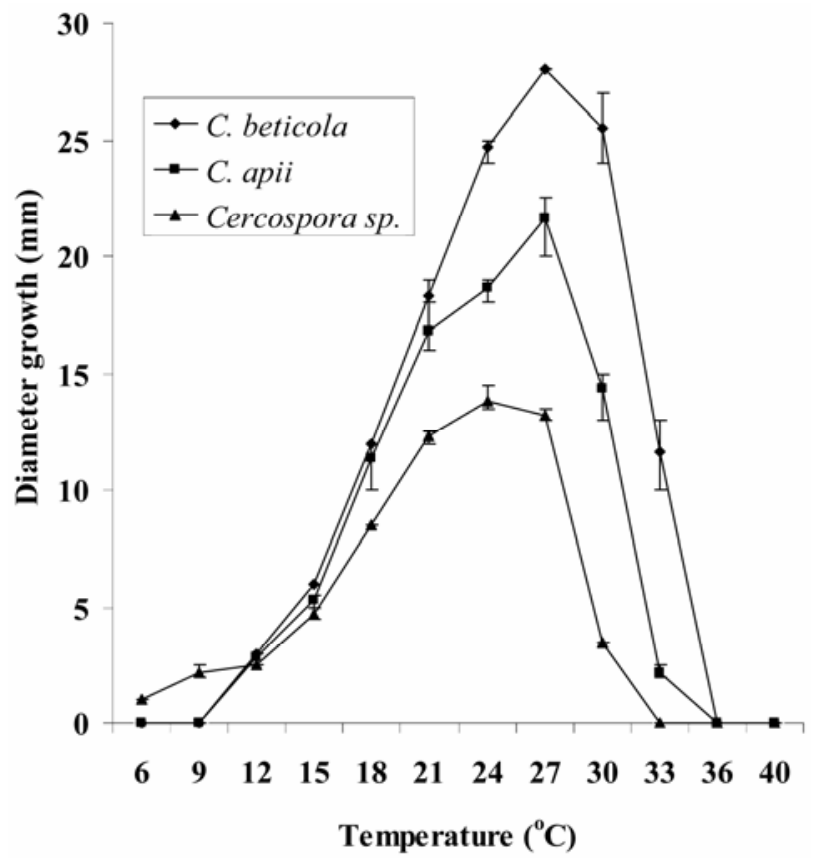

Fig. 1. Colony diameters at different temperatures ranging from 6 to $40^{\circ} \mathrm{C}$ for 8 days on $2 \%$ malt extract agar were calculated for Cercospora apii (CBS 116455), C. beticola (CBS 116456), and Cercospora sp. from Venezuela (CBS 116457).

TABLE 2. Primers designed from calmodulin sequences for the species identification amplifications

\begin{tabular}{llcl}
\hline Primer & \multicolumn{1}{c}{ Sequence $\left(5^{\prime}-3^{\prime}\right)$} & Nucleotide position $^{\mathrm{a}}$ & \multicolumn{1}{c}{ Description } \\
\hline CercoCal-F & CGCGAGGCAGAGCTAACGA & $61-79$ & Positive control forward primer \\
CercoCal-beta & GCCCACCCTCTGCGAATGTA & $117-137$ & Cercospora beticola-specific primer \\
CercoCal-apii & GACCACCCTCTGCAACTGCG & $117-137$ & C. apii-specific primer \\
CercoCal-sp & GCCCACTTTCTGTGACTGCA & $117-137$ & Cercospora sp.-specific primer \\
CercoCal-R & GTGAGGAATTCGGGGAAATC & $275-294$ & Reverse primer \\
\hline
\end{tabular}

a The calmodulin sequence of $C$. apii strain CBS 116455 (GenBank accession no. AY840417) was used to derive the nucleotide positions of the primers. 
temperatures tested. C. beticola grew faster than C. apii (Fig. 1). C. beticola was more tolerant of temperatures higher than $30^{\circ} \mathrm{C}$ ( 1.46 versus $0.26 \mathrm{~mm} /$ day at $33^{\circ} \mathrm{C}$ ).

Phylogenetic analysis. A partition homogeneity test showed that the five data sets were combinable $(P=0.834)$; therefore, the sequence data were analyzed as one combined set. The combined alignment of ITS, ACT, EF, CAL, and HIST contained 41 strains including the three outgroups, and had a total length of 1,611 characters, of which 1,183 were constant, 3 were parsimony uninformative, and 425 were parsimony informative. The topology of the neighbor-joining trees obtained using the different substitution models was the same. A similar topology was found for the most parsimonious trees. Parsimony analysis of the combined data resulted in 12 parsimonious trees, one of which is shown in Figure $2(\mathrm{TL}=465$ steps, $\mathrm{CI}=0.989, \mathrm{RI}=0.997$, and $\mathrm{RC}=0.986)$. From the phylogenetic analysis (Fig. 2), three distinct and wellsupported clades were obtained. The first clade contained isolates of the new Cercospora sp. from Apium spp. (100\% bootstrap support), the second clade contained only Cercospora isolates from B. vulgaris ( $91 \%$ bootstrap support), and the third clade contained Cercospora isolates from both B. vulgaris and Apium spp. (100\% bootstrap support). All the isolates from the third clade were isolated in Europe. The ITS and ACT data sets showed no variation among the isolates from the second and the third clade and no significant variation could be observed between the isolates of these two clades with the EF and HIST data sets. The amount of variation observed within the CAL region of the $C$. beticola and C. apii isolates ( $96 \%$ similarity) was significant and placed these species into two distinct phylogenetic clades, each with a high bootstrap support in the combined analysis.

AFLP analysis. Genetic differences between isolates of the different clades also were confirmed using AFLP analysis. Banding patterns obtained with the EcoRI-A [FAM]/MseI-CT and EcoRI-AT [JOE]/MseI-C primer combinations are shown in Figure 3 . The number and sizes of the polymorphic bands obtained for isolates of the Cercospora sp., using the EcoRI-A [FAM]/MseICT primer combination, show major differences with the profiles obtained for the other two species (Fig. 3A). Although isolates from the $C$. apii and $C$. beticola clades are more similar to each other than to the Cercospora sp., several bands are specific to each of the species, as seen using the EcoRI-A [FAM]/MseI-CT and EcoRI-AT [JOE]/MseI-C primer combinations (Fig. 3). The primer combination EcoRI-AG [NED]/MseI-C also was tested on isolates from the three Cercospora spp. and the banding patterns obtained showed results similar to those obtained with the other two primer combinations (data not shown).

Species identification. Easy and rapid identification of $C$. beticola, C. apii, and the new Cercospora sp. was possible using three multiplex PCR amplifications, each specific for one of the species. A 234-bp fragment, which serves as the positive control, was present for all three species, whereas a 176-bp fragment was observed only for the Cercospora sp. elucidated by the specific internal primer (Fig. 4). Only the 234-bp fragment was present for all other Cercospora spp. tested in our database representing 13 Cercospora spp. (data not shown). Therefore, primers CercoCalbeta, CercoCal-apii, and CercoCal-sp are specific for $C$. beticola, C. apii, and the Cercospora sp., respectively, and can be used for their identification and detection.

\section{DISCUSSION}

Although morphological characteristics frequently are used to identify newly isolated fungi, it is not possible to distinguish C. apii (celery) from $C$. beticola (sugar beet) based solely on morphology. At the onset of this study, these species were considered to be synonymous as part of the $C$. apii sensu lato complex. Our data, however, refute the hypothesis that all morphologically indistinguishable Cercospora forms represent one species $(7,13)$.
C. apii sensu stricto, which typify the $C$. apii sensu lato complex, including $C$. beticola, which is a morphologically similar fungus originally described from sugar beet, are shown to differ genetically and with some cultural characteristics from one another to an extent confirming species-level separation. It is now possible to identify the studied species using these characteristics.

Among the sequence types studied, only CAL strongly supports the split of $C$. apii and C. beticola into two distinct phylogenetic groups. This grouping, however, is confirmed in the growth studies as well as in AFLP analysis. This study shows that the choice and number of loci sequenced can be crucial in elucidating phylogenetic relationships of very closely related species and that using the wrong or an insufficient number of sequence loci could result in erroneous synonymies being proposed. It also shows that phenotypic characteristics, such as growth rates and temperature thresholds, can be very important parameters in the identification of species that are morphologically identical.

From the phylogenetic data obtained, it is clear that $C$. apii occurs mainly on celery, whereas $C$. beticola occurs on sugar beet, and that cross-infection of each other's hosts is rare. We did, however, study three isolates, revealed molecularly as $C$. apii sensu stricto, that were obtained from sugar beet in Europe (CBS 121.31 and CBS 127.31, deposited in 1931, and CBS 152.52 in 1952). The origin of $C$. apii is suspected to be Western Europe, and certainly the species was first described from celery collected in Germany. Because all of the $C$. apii isolates available in this study were from European countries, we do not know whether C. apii has been introduced on Apium spp. in non-European countries. It has been reported that $C$. apii sensu lato isolates can infect hosts other than the ones they were isolated from $(7,22$, 38,42 ). Therefore, it is quite possible that $C$. apii, which grows much more slowly than $C$. beticola at high temperatures (Fig. 1), originally was able to infect sugar beet and compete with $C$. beticola in the early 1900s, when Europe was considerably colder than is currently the case (28). Without doubt, C. beticola has been introduced from Europe to many other parts of the world, and this species now can be found on almost every continent (7; current study). The absence of $C$. apii on fresh diseased leaf material of $B$. vulgaris obtained for the purposes of this study can be ascribed to the unique growth properties of $C$. beticola. It is very probable that the faster growth rate and its ability to easily grow at higher temperatures allow $C$. beticola to out-compete $C$. apii for infection sites on B. vulgaris. It is clear that environmental factors, such as temperature and availability of specific plant species, play an important role in the survival and infection ability of the fungus. Thus, it seems that genotype-environment interactions (24) may play a role in the fitness of species in the C. apii complex.

We illustrated an easy PCR-based method which can be used in laboratories that use basic PCR techniques as a diagnostic tool. Although three PCRs are necessary to distinguish between the three Cercospora spp. affecting celery and sugar beet, it is possible to limit the number of reactions according to the crop from which the pathogen was isolated. Thus far, the new Cercospora sp. has never been isolated from B. vulgaris; however, because both $C$. beticola and $C$. apii have been isolated from sugar beet, it is important to test isolates from that source as possible representatives of both these species. None of the $C$. beticola isolates confirmed as such with molecular data have been isolated from Apium spp.; therefore, it remains possible that $C$. beticola might not infect celery under field conditions.

Because of the major loss in sugar beet production due to Cercospora leaf spot, naturally derived fungicides and synthetic fungicides with broad chemistries are currently being used to control Cercospora spp. infections in this crop (21). Several studies have indicated that $C$. beticola has become resistant to fungicides in the benzimidazole class $(17,33,40)$ and has developed increased tolerance to fungicides in the organotin and triazole classes $(3,5$, 


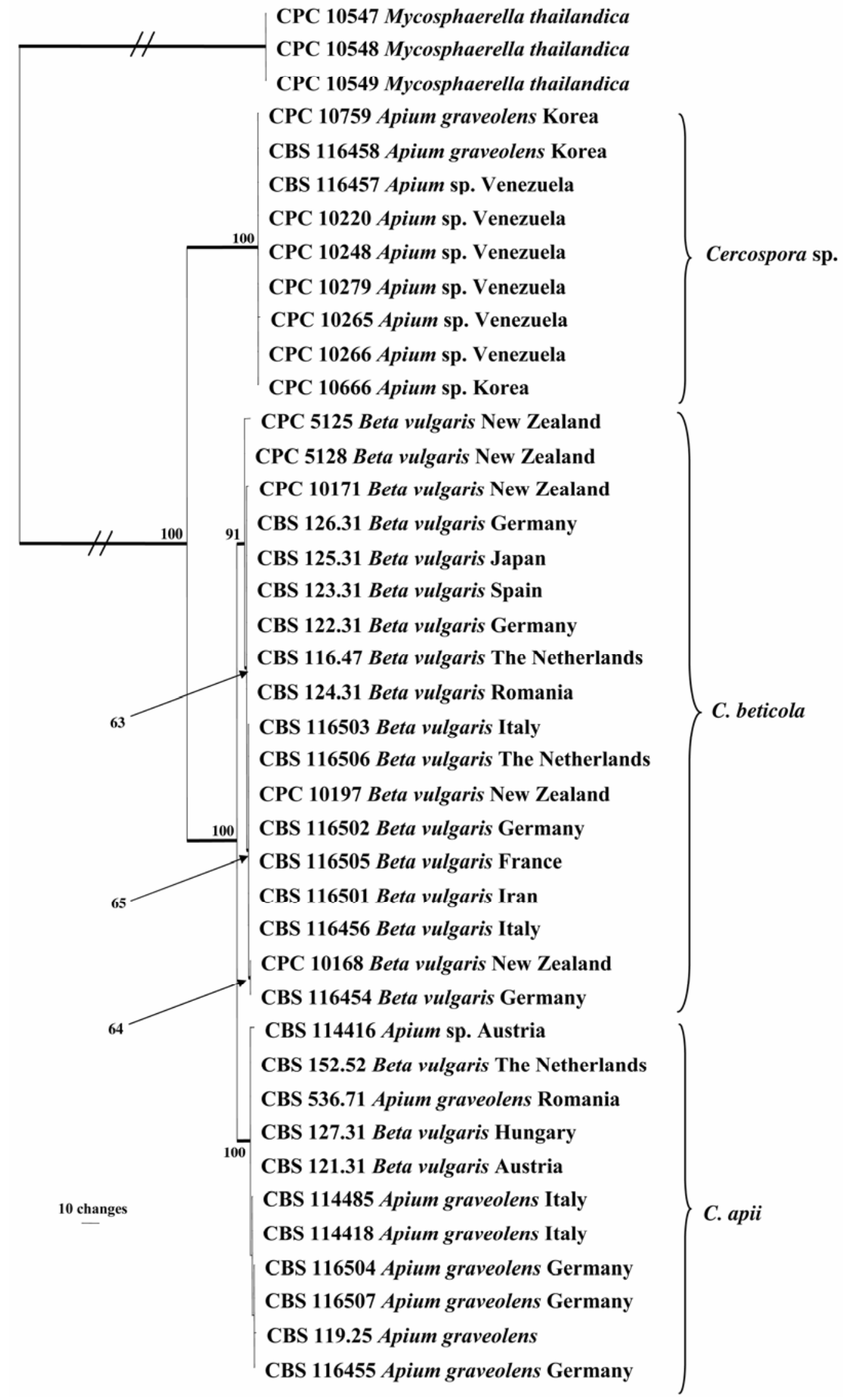

Fig. 2. One of the 12 most parsimonious trees obtained from a heuristic search with 100 random taxon additions of the combined internal transcribed spacer, elongation factor 1- $\alpha$, actin, calmodulin, and histone $\mathrm{H} 3$ sequences alignment. The scale bar shows 10 changes and bootstrap support values from 1,000 replicates are shown in percentages at the nodes. Thickened lines indicate the strict consensus branches. The tree was rooted with three Mycosphaerella thailandica isolates. 
25,41). In order to reduce fungicide tolerance of Cercospora spp. and to control the severity of Cercospora leaf spot disease of sugar beet, the frequent rotation of fungicide chemistries as well as the development of crops resistant to Cercospora infections have been implemented $(21,41)$. Although $C$. beticola seems to be the main agent of Cercospora leaf spot on sugar beet, this study shows that $C$. apii also can be isolated from Cercospora leaf spot lesions on sugar beet. Fungicide trials must be done on these two species to determine their respective resistance levels against different fungicides. If there is a significant difference in their resistance levels, it might provide an explanation for the buildup of fungicide resistance of Cercospora leaf spot in sugar beet. This also can have major implications for the use of fungicides in other crops to which Cercospora spp. are pathogenic.

The relationships of all the other species that have been ascribed to the $C$. apii complex need to be studied in detail. Knowledge of whether species names previously synonymized with $C$. apii are correctly considered superfluous will enable us to better understand the diversity and host specificity of species in this complex, and will enable us to delineate the functional species units that operate in nature. The three species described in this study can be separated from one another not only on the genetic level but also

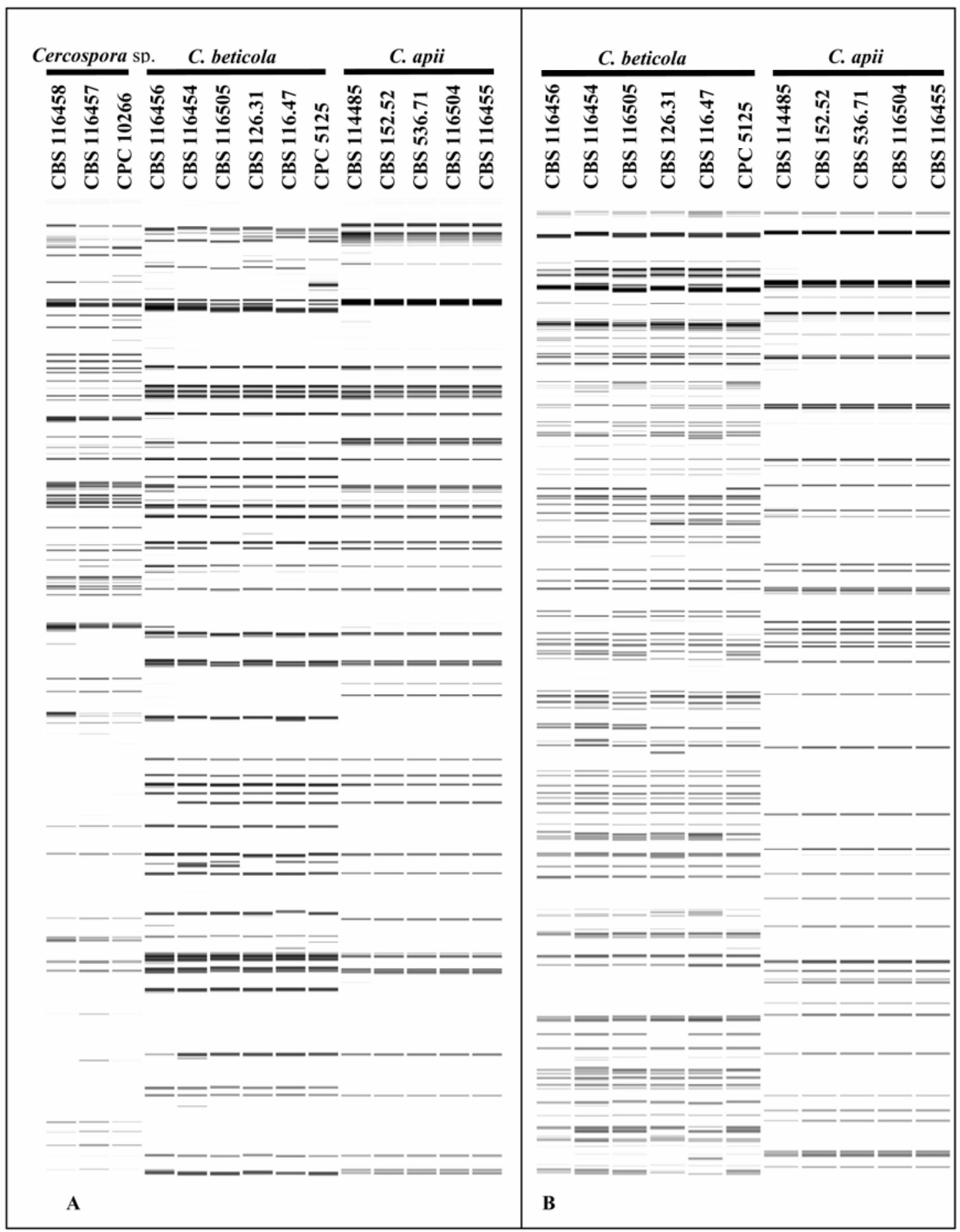

Fig. 3. Visualization of the amplified fragment length polymorphism (AFLP) band patterns were done using Bionumerics software. A, AFLP fingerprints of different isolates of the Cercospora sp., Cercospora beticola, and C. apii using primer combination EcoRI-A [FAM]/MseI-CT. B, AFLP fingerprints of C. beticola and C. apii isolates using primer combination EcoRI-AT [JOE]/MseI-C. 
by the ecological niche of each of the species. The genotypic differences observed for the three Cercospora spp. can be linked most of the time to the ecological differences between them; for example, cardinal temperature ranges and host identity.

From our data, it is clear that Chupp (6) was not totally incorrect when he proposed that Cercospora spp. were restricted to specific host genera or families. If this concept could be used for all the Cercospora spp.-host combinations, it would be easy to identify Cercospora spp. based on their hosts. Unfortunately, the present study confirms that this concept is not applicable to the genus as whole. For instance, the Cercospora sp. present on typical Cercospora leaf spot symptoms of celery in Venezuela and Korea is a distinct species that matches none of the 200 Cercospora sequences in our database. This species grows much more slowly than $C$. apii, and is unable to grow at $33^{\circ} \mathrm{C}$ or above, but can grow at much lower temperatures than $C$. apii; for example, at 6 to $10^{\circ} \mathrm{C}$. Based on phylogenetic and AFLP analyses, this species is different from $C$. apii as well as $C$. beticola. A population representing more than 50 celery plants was collected of this species in Venezuela, indicating that it obviously is well established on this host. The fact that this species also occurs on celery in Korea suggests that, rather than representing a pathogen that normally grows on another host but occasionally occurs on celery by chance alone, it is instead an established pathogen of celery. It probably has been overlooked in the past due to its morphological similarity to $C$. apii and similar host symptomatology. This discovery of such a widespread cryptic species on a well-studied host like celery, however, does stimulate one to question whether similar cryptic species could exist within additional "common" pathogens that we currently accept as having wide host ranges. The present study illustrates how important it is to the plant pathology community to lodge reference strains of the pathogens they are working with in long-term storage in publicly accessible collections. Had it not been for the plant pathologists who lodged their $C$. apii strains in the early 1900s, it would not have been possible to prove the presence of different Cercospora spp. on celery, or the natural occurrence of $C$. apii on sugar beet. This

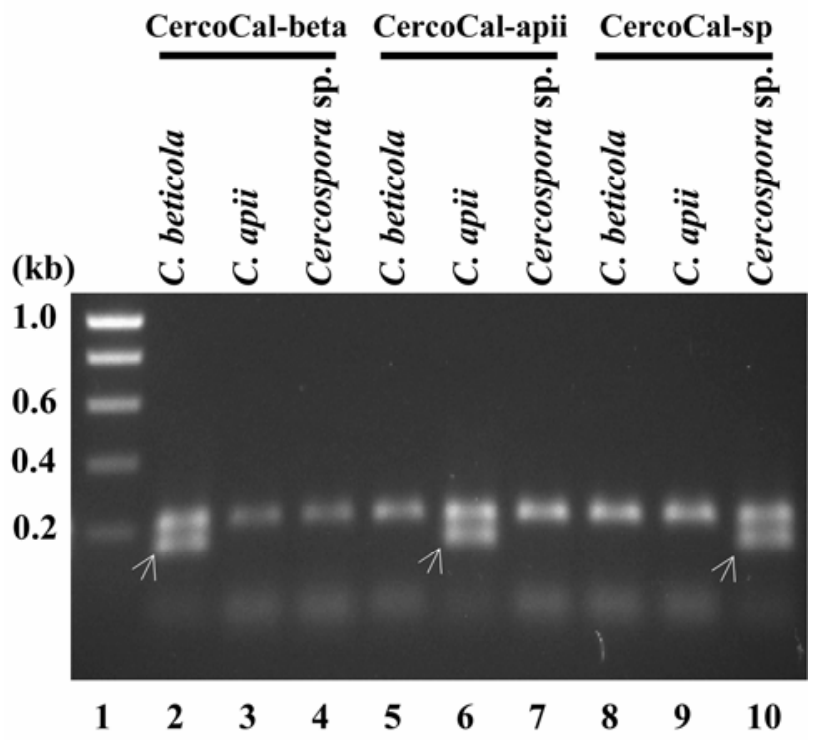

Fig. 4. Identification of Cercospora beticola, C. apii, and the new Cercospora sp. using the different species-specific (CercoCal) primers. Lane 1 contains the DNA marker. The 234-bp fragment, the positive control, is present for all the polymerase chain reaction amplifications done (lanes 2 to 10). The species-specific fragment (176 bp, indicated with an arrow) can be observed only when the amplification reaction contains $C$. beticola (CBS 116456) DNA with primer CercoCal-beta (lane 2), C. apii (CBS 116455) with primer CercoCal-apii (lane 6), or Cercospora sp. (CBS 116457) with primer CercoCal-sp (lane 10). riddle, in spite of the advanced techniques employed here, remains unresolved to this day.

\section{ACKNOWLEDGMENTS}

This research was financially supported by the CBS-Odo van Vloten Stichting, and the Royal Netherlands Academy of Arts and Sciences. We thank D. Shin and N. Pons for supplying us with the infected Apium leaf materials from Korea and Venezuela, respectively, which were crucial for the identification of a new Cercospora sp. on celery; U. Braun for his assistance regarding the tracing of type materials of $C$. apii and C. beticola; and R. C. Summerbell for his comments on an earlier version of the manuscript.

\section{LITERATURE CITED}

1. Anderson, F., and Delhey, R. 1997. Mancha foliar de Modiolastrum australe (Malvaceae), causada por Cercospora gossypina (Hyphomycetes). Bol. Soc. Argent. Bot. 33:47-52.

2. Berger, R. D., and Hanson, E. W. 1963. Pathogenicity, host-parasite relationship, and morphology of some forage legume Cercosporae, and factors related to disease development. Phytopathology 53:500-508.

3. Bugbee, W. M. 1995. Cercospora beticola tolerant to triphenyltin hydroxide. J. Sugar Beet Res. 30:167-174.

4. Carbone, I., and Kohn, L. M. 1999. A method for designing primer sets for speciation studies in filamentous ascomycetes. Mycologia 91:553556.

5. Cerato, C., and Grassi, G. 1983. Tolerance of organo-tin compounds among Cercospora beticola isolates. Inf. Fitopatol. 33:67-69.

6. Chupp, C. 1954. A Monograph of the Fungus Genus Cercospora. Published by the author, Ithaca, NY.

7. Crous, P. W., and Braun, U. 2003. Mycosphaerella and its anamorphs: 1 Names published in Cercospora and Passalora. Centraalbureau voor Schimmelcultures, Utrecht, The Netherlands.

8. Crous, P. W., Gams, W., Wingfield, M. J., and van Wyk, P. S. 1996. Phaeoacremonium gen. nov. associated with wilt and decline diseases of woody hosts and human infections. Mycologia 88:786-796.

9. Crous, P. W., Groenewald, J. Z., Pongpanich, K., Himaman, W., Arzanlou, M., and Wingfield, M. J. 2004. Cryptic speciation and host specificity among Mycosphaerella spp. occurring on Australian Acacia species grown as exotics in the tropics. Stud. Mycol. 50:457-469.

10. Crous, P. W., Groenewald, J. Z., Risede, J.-M., and Hywel-Jones, N. L. 2004. Calonectria species and their Cylindrocladium anamorphs: Species with sphaeropedunculate vesicles. Stud. Mycol. 50:415-430.

11. Crous, P. W., Kang, J.-C., and Braun, U. 2001. A phylogenetic redefinition of anamorph genera in Mycosphaerella based on ITS rDNA sequences and morphology. Mycologia 93:1081-1101.

12. Duffus, J. E., and Ruppel, E. G. 1993. Diseases. Pages 346-427 in: The Sugar Beet Crop. D. A. Cooke and R. K. Scott, eds. Chapman and Hall, London.

13. Ellis, M. B. 1971. Dematiaceous Hyphomycetes. Commonwealth Mycological Institute, Kew, Surrey, UK.

14. Farris, J. S., Källersjö, M., Kluge, A. G., and Bult, C. 1994. Testing significance of incongruence. Cladistics 10:315-320.

15. Fresenius, G. 1863. Beiträge zur Mykologie 3. Heinrich Ludwig Brömmer Verlag, Frankfurt, Germany.

16. Gams, W., Hoekstra, E. S., and Aptroot, A. 1998. CBS Course of Mycology, 4th ed. Centraalbureau voor Schimmelcultures, Baarn, The Netherlands.

17. Georgopoulos, S. G., and Dovas, C. 1973. Occurrence of Cercospora beticola strains resistant to benzimidazole fungicides in northern Greece. Plant Dis. Rep. 62:321-324.

18. Goodwin, S. B., Dunkley, L. D., and Zismann, V. L. 2001. Phylogenetic analysis of Cercospora and Mycosphaerella based on the internal transcribed spacer region of ribosomal DNA. Phytopathology 91:648-658.

19. Hillis, D. M., and Bull, J. J. 1993. An empirical test of bootstrapping as a method for assessing confidence in phylogenetic analysis. Syst. Biol. 42:182-192.

20. Holtschulte, B. 2000. Cercospora beticola-world-wide distribution and incidence. Pages 5-16 in: Cercospora beticola Sacc. Biology, Agronomic Influences and Control Measures in Sugar Beet IIRB. M. J. C. Asher, B. Holtschulte, M. M. Richard, F. Rosso, G. Steinrucken, and R. Beckers, eds. International Institute for Beet Research, Belgium.

21. Ioannidis, P. M., and Karaoglanidis, G. S. 2000. Resistance of Cercospora beticola Sacc. to fungicides. Adv. Sugar Beet Res. IIRB 2:123-147.

22. Johnston, E. M., and Valleau, W. D. 1949. Synonymy in some common species of Cercospora. Phytopathology 39:763-770. 
23. Kaiser, W. J., and Lukezic, F. L. 1965. Brown spot disease of banana caused by Cercospora hayi. Phytopathology 55:977-980.

24. Kang, M. S., and Gauch, H. G. 1996. Genotype-by-Environment Interaction. CRC Press, Boca Raton, FL.

25. Karaoglanidis, G. S., Ioannidis, P. M., and Thanassoulopoulos, C. C. 2000. Reduced sensitivity of Cercospora beticola to sterol-demethylationinhibiting fungicides. Plant Pathol. 49:567-572.

26. Koike, S. T., Gilbertson, R. L., and Davis, R. M. 2004. University of California IPM Pest Management Guidelines: Celery. Online publication UC ANR 3439.

27. Kucharek, T. 2004. University of Florida Institute of Food and Agricultural Sciences. Florida Plant Disease Management Guide: Carrot. 2004 Florida Plant Disease Management Guide. Online publication PDMG-V335 .

28. Luterbacher, J., Dietrich, D., Xoplaki, E., Grosjean, M., and Wanner, H. 2004. European seasonal and annual temperature variability, trends, and extremes since 1500. Science 303:1499-1503.

29. Page, R. D. M. 1996. TREEVIEW: An application to display phylogenetic trees on personal computers. Comput. Appl. Biosci. 12:357-358.

30. Pretorius, M. C., Crous, P. W., Groenewald, J. Z., and Braun, U. 2003. Phylogeny of some cercosporoid fungi from Citrus. Sydowia 55:286-305.

31. Rayner, R. W. 1970. A Mycological Colour Chart. Commonwealth Mycological Institute and British Mycological Society, Kew, Surrey, UK.

32. Rossi, V., Battilani, P., Chiusa, G., Giosue, S., Languasco, L., and Racca, P. 2000. Components of rate-reducing resistance to Cercospora leaf spot in sugarbeet: Conidiation length, spore yield. J. Plant Pathol. 82:125-131.

33. Ruppel, E. G., and Scott, P. R. 1974. Strains of Cercospora beticola resistant to benomyl in the USA. Plant Dis. Rep. 58:434-436.
34. Saccardo, P. A. 1876. Fungi Veneti novi vel critici. Series V. Nuovo Giorn. Bot. Ital. 8:162-211.

35. Shane, W. W., and Teng, P. S. 1992. Impact of Cercospora leaf spot on root weight, sugar yield, and purity of Beta vulgaris. Plant Dis. 76:812820 .

36. Stewart, E. L., Liu, Z., Crous, P. W., and Szabo, L. J. 1999. Phylogenetic relationships among some cercosporoid anamorphs of Mycosphaerella based on rDNA sequence analysis. Mycol. Res. 103:1491-1499.

37. Tessmann, D. J., Charudattan, R., Kistler, H. C., and Rosskopf, E. N. 2001. A molecular characterization of Cercospora species pathogenic to water hyacinth and emendation of $C$. piaropi. Mycologia 93:323-334.

38. Vestal, E. F. 1933. Pathogenicity, host response and control of Cercospora leaf spot of sugarbeet. Iowa Agric. Exp. Stn. Res. Bull. 168:43-72.

39. Vos, P., Hogers, R., Bleeker, M., Reijans, M., van der Lee, T., Hornes, M., Frijters, A., Pot, J., Peleman, J., Kuiper, M., and Zabeau, M. 1995. AFLP: A new technique for DNA fingerprinting. Nucleic Acids Res. 23:44074414.

40. Weiland, J. J., and Halloin, J. M. 2001. Benzimidazole resistance in Cercospora beticola sampled from sugarbeet fields in Michigan, USA. Can. J. Plant Pathol. 23:78-82.

41. Weiland, J., and Koch, G. 2004. Pathogen profile. Sugarbeet leaf spot disease (Cercospora beticola Sacc.). Mol. Plant Pathol. 5:157-166.

42. Welles, C. G. 1933. Taxonomic studies on the genus Cercospora in the Philippine Islands. Am. J. Bot. 12:195-218.

43. White, T. J., Bruns, T., Lee, S., and Taylor, J. 1990. Amplification and direct sequencing of fungal ribosomal RNA genes for phylogenetics. Pages 282-287 in: PCR Protocols. A Guide to Methods and Applications. M. A. Innis, D. H. Gelfand, J. J. Sninsky, and T. J. White, eds. Academic Press, San Diego, CA 